\title{
Female Reproductive System Adenofibroma
}

National Cancer Institute

\section{Source}

National Cancer Institute. Female Reproductive System Adenofibroma. NCI Thesaurus.

Code C8984.

A benign or borderline neoplasm characterized by the presence of connective tissue stroma and epithelial structures. It occurs in the ovary, fallopian tube, uterine corpus, and cervix. 